\title{
Interactive comment on "Effective densities of soot particles and their relationships with the mixing state at an urban site of the Beijing mega-city in the winter of 2018' by Hang Liu et al.
}

Hang Liu et al.

liuhang@mail.iap.ac.cn

Received and published: 25 October 2019

The attachment includes: the revised manuscript, the revised supplementary, the reply to the Anonymous Referee. Please refer to the attachment for specific reply. (line 680-765).

Please also note the supplement to this comment: https://www.atmos-chem-phys-discuss.net/acp-2019-526/acp-2019-526-AC1supplement.pdf 
2019.

ACPD

Interactive

comment

Printer-friendly version

Discussion paper 